\title{
The Importance of Checking Leishmania Promastigotes Viability in the Proteomics Analysis of Secretions
}

\author{
Sekresyonların Proteomiks Analizinde Leishmania Promastigotların Canlılıklarının Kontrol \\ Edilmesinin Önemi
}

\author{
Sajad Rashidi (D), Kurosh Kalantar² (D), Davood Rostamzadeh ${ }^{3}$ (D), Gholamreza Hatam ${ }^{4 \star}$ (D) \\ 1Department of Parasitology and Mycology, Shiraz University of Medical Sciences, Shiraz, Iran \\ 2Department of Immunology, Shiraz University of Medical Sciences, Shiraz, Iran \\ ${ }^{3}$ Immunology Research Center, Tabriz University of Medical Sciences, Tabriz, Iran \\ ${ }^{4}$ Basic Sciences in Infectious Diseases Research Center, Shiraz University of Medical Sciences, Shiraz, Iran
}

Cite this article as: Rashidi S, Kalantar K, Rostamzadeh D, Hatam G. The Importance of Checking Leishmania Promastigotes Viability in the Proteomic analysis of Secretions. Turkiye Parazitol Derg 2018; 42(4): 245-8.

\section{ABSTRACT}

Objective: The aim of the present study was to compare the efficacy of checking the viability of Leishmania promastigote by flow cytometry using propidium iodide $(\mathrm{PI})$ and microscopic method using trypan blue (TB) before proteomics analysis of the secretions.

Methods: The promastigotes $(6 \times 109)$ of Leishmania infantum in the exponential growth phase were transferred to serum-free media. Then, the viability of promastigotes was checked and compared with flow cytometry and microscopic method at $0,2,3,4,5$, and $72 \mathrm{~h}$.

Results: Flow cytometry did not show many dead cells at 0 to $4 \mathrm{~h}$, and the viability was approximately $98 \%$. The percentage of the dead promastigotes increased to $8 \%$ at $5 \mathrm{~h}$ and $17 \%$ at $72 \mathrm{~h}$. Meanwhile, the microscopic method using TB did not show any dead cell after 4 and $72 \mathrm{~h}$, and the viability was $100 \%$.

Conclusion: The present study confirms the importance of flow cytometry using PI in checking the viability of Leishmania promastigotes, especially before the proteomics analysis of the secretions. It also shows that flow cytometry using PI is more sensitive than microscopic method using TB.

Keywords: Flow cytometry, trypan blue, viability, Leishmania, proteomics

Received: $30.12 .2018 \quad$ Accepted: 18.06.2018

Öz

Amaç: Bu çalışmanın amacı, sekresyonların proteomik analizinden önce, Leishmania promastigotunun canlılığııın tripan mavisi (TB) kullanılan mikroskopik yöntem ve propidum iyodid (PI) kullanılan akış sitometrisi ile kontrol edilmesinin etkinliğini karşılaştırmaktır.

Yöntemler: Üstel büyüme fazında Leishmania infantum promastigotları $(6 \times 109)$ serumsuz ortama aktarıldı. Daha sonra promastigotların canlılı̆̆ı 0, 2, $3,4,5$ ve 72 nci saatlerde akış sitometrisi ve mikroskopik yöntemle kontrol edildi ve karşılaştıııldı.

Bulgular: Akış sitometrisi 0 ila 4 saat arasında çok ölü hücre göstermedi ve canlılık yaklaşık \% 98 idi. Ölü promastigotların yüzdesi 5 saatte \% ${ }^{\prime}$ e ve 72 saatte \%17'ye yükseldi. Diğer yandan, TB kullanan mikroskobik yöntemde 4 ve 72 saat sonra herhangi bir ölü hücre gözlenmedi ve canllık \% 100 idi. Sonuç: Bu çalışma, özellikle sekresyonların proteomik analizinden önce, Leishmania promastigotlarının canlıı̆ının kontrol edilmesinde PI kullanılarak uygulanan akış sitometrisinin önemini doğrulamaktadır. Ayrıca PI kullanılan akış sitometrisinin, TB kullanılan mikroskopik yöntemden daha duyarlı olduğunu da göstermektedir.

Anahtar kelimeler: Akış sitometrisi, tripan mavisi, canlılık, leishmania, proteomik

Geliş Tarihi: 30.12 .2018

Kabul Tarihi: 18.06.2018

The abstract of this article was presented at the $3^{\text {rd }}$ International and the $10^{\text {th }}$ National Congress of Parasitology and Parasitic Diseases of Iran (NICOPA10, no.: HN10104350404).

Bu yazının özeti 3. Uluslararası ve 10. Ulusal iran Parazitoloji ve Paraziter Hastalıklar Kongresi'nde sunulmuştur (NICOPA10, no.: HN10104350404).

Corresponding Author / Sorumlu Yazar: Gholamreza Hatam E.mail: hatamghr@sums.ac.ir DOI: $10.5152 /$ tpd.2018.5834 


\section{INTRODUCTION}

Leishmaniasis is a major parasitic vector-borne disease caused by a family of obligate intracellular dimorphic protozoa of the genus Leishmania. The life cycle of Leishmania includes extracellular promastigote in sandflies and amastigote stage that presents in mammals within mononuclear phagocyte cells $(1,2)$. To our knowledge, there is no effective treatment with reduced side effect for leishmaniasis in the literature. Therefore, improving the diagnosis, treatment, and vaccination of leishmaniasis is urgent for the control and prevention of this disease $(3,4)$.

Nowadays, most studies on Leishmania are performed using promastigote as this form is more adaptable in vitro, and the required technology for its cultivation is not tedious and laborious (5). The antigenic targets in secretions of Leishmania promastigotes are suitable sources for designing vaccines and diagnosing leishmaniasis since these antigens are considered as stimulants of the immune system $(6,7)$. Therefore, the preparation of excretory-secretory antigens from live promastigotes (viable cells $\geq 98 \%$ ) is a considerable advantage, especially in the proteomics research on secretions of Leishmania parasites.

Proteome refers to a set of proteins that have been encoded by the genome (8) and defined as the analysis of proteins to determine their unique identity, quantity, function, and interaction (9). Evidence also shows that proteomics is practically suitable for the analysis of the proteome of the Leishmania genus (10). Recently, researchers have attempted to use this technique to identify immunodominant antigens in Leishmania parasites and to introduce new targets for vaccines (11).

The preparation of a high-quality sample is an important issue in the proteomics approaches (12). Therefore, it is very essential to provide a reliable method that can determine the viability of Leishmania promastigotes before proteomics analysis of the secretions.

For performing some experimental procedures, checking cell viability is the first step (13). Most of the viability tests are based on the integrity of the cell membranes. Vital dyes, such as trypan blue (TB), can penetrate selectively into the dead cells, but the viable cells do not permit these dyes to penetrate the cells so the live cells remain unstained. Therefore, optical microscopy methods are used to count the number of stained and unstained cells using a Neubauer chamber (14).

One of the major practical assays widely used to check the viability is flow cytometry with propidium iodide (PI) staining (15). The PI function is similar to TB and penetrates the dead cells that produce a complex with DNA (16). The advantages of the $\mathrm{PI}$ assay are its high accuracy and the possibility of running many samples in a short time. There are only few studies in the literature that have been conducted to improve the TB exclusion test by making the adaptations with flow cytometry (17).

To the best of our knowledge, few studies have checked the viability of Leishmania promastigotes before proteomics analysis of the secretions (18-20). Based on various results in this regard, the aim of the present study was to evaluate and to check the viability of Leishmania infantum promastigotes by flow cytometry using $\mathrm{PI}$ in comparison to microscopic method using TB.

\section{METHODS}

\section{Sample preparation and promastigote culture}

L. infantum strain (MCAN/IR/07/Moheb-gh) was provided by the Department of Parasitology and Mycology of Medical Sciences, Shiraz, Iran. L. infantum promastigotes were mass cultivated at $25^{\circ} \mathrm{C}$ in the Schneider's insect culture media (Sigma Chemical Co., St. Louis, MO, USA) supplemented with $20 \%$ (v/v) bovine serum (heat inactivation requires the serum to be at $56{ }^{\circ} \mathrm{C}$ for $50 \mathrm{~min}), 100 \mathrm{U} / \mathrm{mL}$ penicillin, and $100 \mu \mathrm{g} / \mathrm{mL}$ streptomycin. Then, $6 \times 10^{9}$ promastigotes were collected in the exponential growth phase (day 3) by centrifugation at $2000 \times \mathrm{g}$ for $10 \mathrm{~min}$ at $4{ }^{\circ} \mathrm{C}$ and washed three times with RPMI-1640 (Shellmax Co., China) serum-free media (21).

Washed promastigotes were transferred to $10 \mathrm{~mL}$ RPMI-1640 serum-free media for secretions assay. The number of promastigotes was determined by a Neubauer hemocytometer (22). Then, the viability of promastigotes was indicated at $0,2,3,4,5$, and 72 $\mathrm{h}$ by flow cytometry using $\mathrm{PI}$ and microscopic method using TB.

\section{Flow cytometry assay using PI}

Ten thousand promastigotes in $500 \mu \mathrm{L}$ of the RPMI-1640 serum-free media were incubated in the presence of $5 \mu \mathrm{L} \mathrm{PI}$ solution ( $1 \mathrm{mg} / \mathrm{mL}$; Sigma Chemicals Co.) for $5 \mathrm{~min}$ at $23-25^{\circ} \mathrm{C}$ (19). Suspended promastigotes were run by flow cytometry (BD FACSCalibur $^{\circledR}$, USA) set to excitation at $493 \mathrm{~nm}$ and emission at $636 \mathrm{~nm}$ wavelengths. The results were analyzed by the FlowJo software, version 7 (LLC, USA) at 0, 2, 3, 4, 5, and $72 \mathrm{~h}$.

\section{Microscopic method using TB}

In the TB exclusion test, $10 \mu \mathrm{L}$ of TB was added to $10 \mu \mathrm{L}$ of RPMI1640 serum-free media containing 10,000 promastigotes, and the viability was immediately determined at $0,2,3,4,5$, and 72 h (23). In PI and TB experiments, the promastigotes that were exposed to methanol were used as a positive control.

\section{Statistical Analysis}

Data were expressed as mean \pm SD of at least three independent experiments. The statistical significant difference between the groups was evaluated using the GraphPad software (GraphPad San Diego, CA, USA). The statistical test was evaluated using the one-way analysis of variance. A $p<0.05$ was considered statistically significant.

\section{RESULTS}

In the present study, the results showed that the PI can precisely discriminate dead promastigotes against viable promastigotes. Interestingly, the percent of dead cells using PI was shown to be time dependent. The cell viability using PI was approximately $98 \%$ at $0,2,3$, and $4 \mathrm{~h}$. However, the viability declined to $92 \%$ and $83 \%$ after 5 and $72 \mathrm{~h}$, respectively (Figures $1 \mathrm{a}, \mathrm{b}$ ).

Furthermore, the same experiment was performed in regard to TB to evaluate the viability. The percent of the viability of promastigotes in respect to TB was not inconsistent with the PI results. Surprisingly, all promastigotes were viable after 5 and $72 \mathrm{~h}$. In the positive control, the dead cells were measured at approximately $98 \%$ by flow cytometry using PI (Figures 1a, b) and 100\% by microscopic method using TB. 

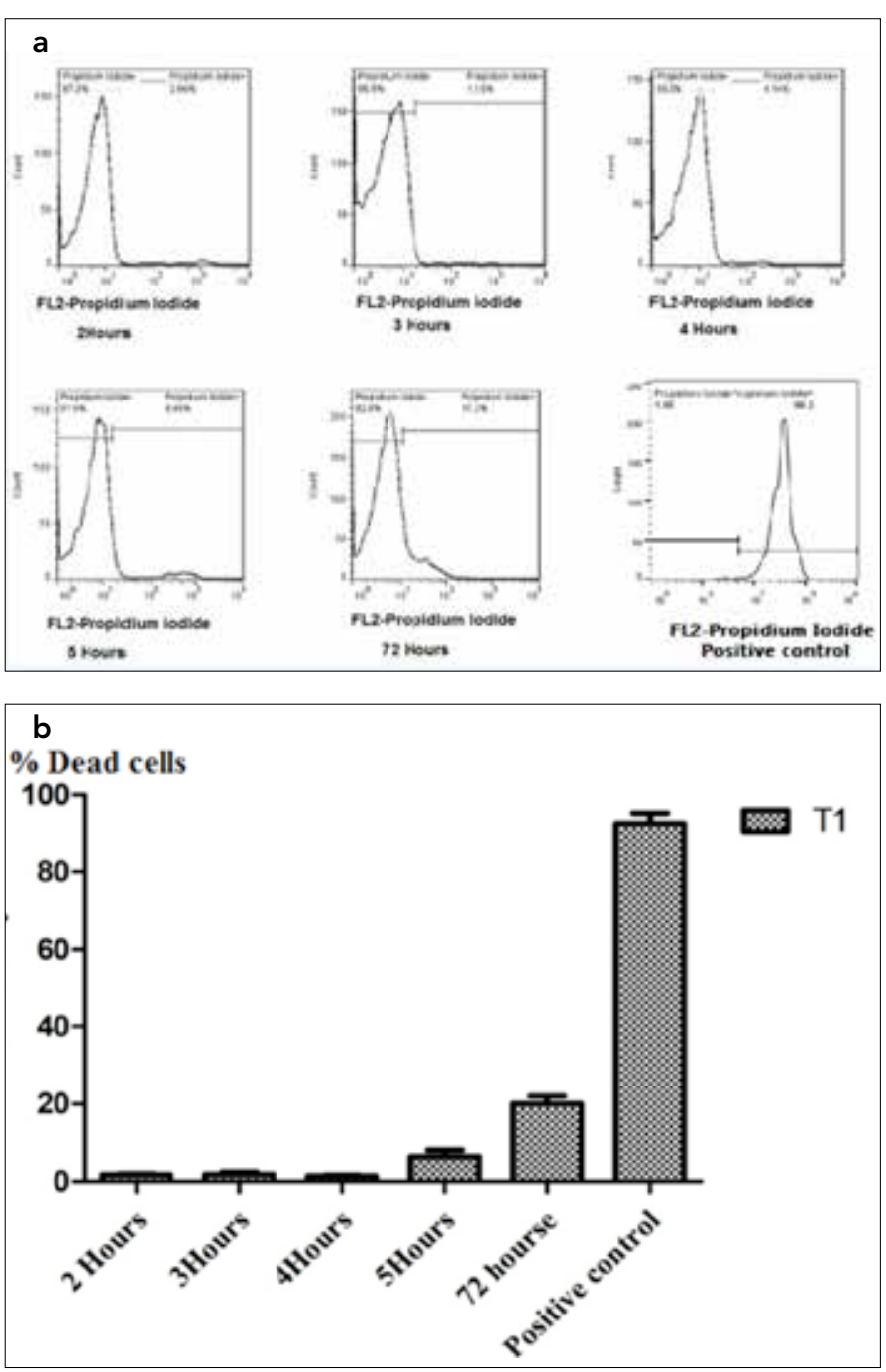

Figure 1. a, b. The results of flow cytometry with PI for checking the viability of $\mathrm{L}$. infantum promastigotes at 2, 3, 4, 5, and $72 \mathrm{~h}$ and positive control (a) Values are expressed as mean \pm SD of three independent experiments (b).

\section{DISCUSSION}

Some proteomics studies in Leishmania parasites present different antigens that could be effective in the development of vaccines, drugs, and diagnosis of leishmaniasis (7, 24-27). Obtaining secretions from the viable cells is pivotal for having a good interpretation of the results of proteomics experiments (28). Since the contamination of secretions with dead parasites leads to some unreliable data, checking the viability is necessary in this regard.

A proteomics research on the secretions of Leishmania promastigotes did not use a precise method to check the viability of promastigotes (29). The findings by Cuervo et al. (18) showed that the best time point for collecting secretions is $3 \mathrm{~h}$ based on the TB method. However, our findings indicated that the microscopic method using TB cannot detect dead cells at $3 \mathrm{~h}$, and the accuracy of the results will probably be decreased.

In 2015, Kumar et al. (19) detected the immunostimulant antigens in soluble exogenous antigens in Leishmania donovani and used the microscopic method to check the viability of promastigotes. Their findings identified that the appropriate time for the evaluation of viability is approximately $72 \mathrm{~h}$. Although our microscopy results were in accordance with their study, the flow cytometry results showed that $17 \%$ of promastigotes are not viable after 72 h. The microscopic method using TB appears to be imprecise and can lead to an overestimation of the live cells, especially in cases in which we intend to check the viability of many cells (30).

Our findings for $\mathrm{PI}$ are somehow in line with the study by Braga et al. (20). They used the flow cytometry assay to check the viability of promastigotes within 2-8 $\mathrm{h}$ and proposed that the optimum time for collecting the promastigote secretions is $6 \mathrm{~h}$ (19).

To our knowledge, few studies have been conducted to improve the TB exclusion test using flow cytometry (17). They suggested that using TB in flow cytometry could also be precise. However, the use of TB in flow cytometry based on the literature is not common. In addition, they did not compare their results with PI.

\section{CONCLUSION}

The present study proposes and confirms that flow cytometry using $\mathrm{Pl}$ staining should be prioritized for checking the viability of promastigotes in the proteomics analysis of Leishmania secretions. In addition, our findings proved that the optimum incubation time is $4 \mathrm{~h}$ for obtaining secretions without many dead cells.

Peer-review: Externally peer-reviewed.

Author Contributions: Concept - S.R., G.H.; Design - S.R., G.H.; Supervision - G.H.; Resources - G.H.; Materials - G.H.; Data Collection and/ or Processing - S.R., K.K., D.R., G.H.; Analysis and/or Interpretation S.R., K.K.; Literature Search S.R.; Writing Manuscript - S.R., K.K., G.H.; Critical Review - G.H.

Acknowledgements: We hereby gratefully acknowledge Dr. Jose Maria Alunda Rodriguez for his helpful discussion and comments on the manuscript.

Conflict of Interest: Authors have no conflicts of interest to declare.

Financial Disclosure: This work was supported by Shiraz University of Medical Sciences (Grant No: 94-7597).

Hakem Değerlendirmesi: Dış bağımsız.

Yazar Katkıları: Fikir - S.R., G.H.; Tasarım - S.R., G.H.; Denetleme - G.H.; Kaynaklar - G.H.; Malzemeler - G.H.; Veri Toplanması ve/veya Işlemesi S.R., K.K., D.R., G.H.; Analiz ve/veya Yorum - S.R., K.K.; Literatür Taraması - S.R.; Yazıyı Yazan - S.R., K.K., G.H.; Eleştirel İnceleme - G.H.

Teşekkür: Dr. Jose Maria Alunda Rodriguez'e makaleye yaptığı tartışma ve yorumlar için minnetle teşekkür ediyoruz.

Çıkar Çatışması: Yazarlar çıkar çatışması bildirmemişlerdir.

Finansal Destek: Bu çalışma Şiraz Üniversitesi tarafından desteklenmiş̧ir (No: 94-7597).

\section{REFERENCES}

1. Beyhan YE, Çelebi B, Ergene O, Mungan M. Seroprevalance of Leishmaniasis in Dogs from Hatay and Burdur Provinces of Turkey and Northern Cyprus. Turkiye Parazitol Derg 2016; 40: 9-12. [CrossRef] 
2. Tlamçani Z, Er-Rami M. The current status of cutaneous leishmaniasis in Morocco. Turkiye Parazitol Derg 2014; 38: 5-8. [CrossRef]

3. Alkhawajah A, Larbi E, Al-Gindan Y, Abahussein A, Jain S. Treatment of cutaneous leishmaniasis with antimony: intramuscular versus intralesional administration. Ann Trop Med Parasitol 1997; 91: 899905. [CrossRef]

4. Rasouli M, Hoseini AZ, Kazemi B, Alborzi A, Kiany S. Expression of recombinant heat-shock protein 70 of MCAN/IR/96/LON-49, a tool for diagnosis and future vaccine research. Iran J Immunol 2009; 6: 75-86.

5. Mohammadi-Ghalehbin B, Hatam GR, Sarkari B, Mohebali M, Zarei $Z$, Jaberipour $M$, et al. A Leishmania infantum FML-ELISA for the detection of symptomatic and asymptomatic canine visceral leishmaniasis in an endemic area of Iran. Iran J Immunol 2011; 8: 244-50.

6. Gour JK, Kumar V, Singh N, Bajpai S, Pandey HP, Singh RK. Identification of Th1-responsive leishmanial excretory-secretory antigens (LESAs). Exp Parasitol 2012; 132: 355-61. [CrossRef]

7. Rashidi S, Kalantar K, Hatam G. Using proteomics as a powerful tool to develop a vaccine against Mediterranean visceral leishmaniasis. J Parasit Dis 2018; 42: 162-70. [CrossRef]

8. Wilkins MR, Sanchez JC, Gooley AA, Appel RD, Humphery-Smith I, Hochstrasser DF, et al. Progress with proteome projects: why all proteins expressed by a genome should be identified and how to do it. Biotechnol Genet Eng Rev 1996; 13: 19-50. [CrossRef]

9. Herosimczyk A, Dejeans N, Sayd T, Ozgo M, Skrzypczak W, Mazur A. Plasma proteome analysis: 2D geld and chips. J Physiol Pharmacol 2006; 57: 81-93.

10. Murray HW, Berman JD, Davies CR, Saravia NG. Advances in leishmaniasis. Lancet 2005; 366: 1561-77. [CrossRef]

11. Gupta SK, Sisodia BS, Sinha S, Hajela K, Naik S, Shasany AK, et al. Proteomic approach for identification and characterization of novel immunostimulatory proteins from soluble antigens of Leishmania donovani promastigotes. Proteomics 2007; 7: 816-23. [CrossRef]

12. Chandramouli K, Qian PY. Proteomics: challenges, techniques and possibilities to overcome biological sample complexity. Hum Genomics Proteomics 2009; 2009.

13. Lévesque A, Paquet A, Pagé M. Measurement of tumor necrosis factor activity by flow cytometry. Cytometry 1995; 20: 181-4. [CrossRef]

14. Tennant JR. Evaluation of the trypan blue technique for determination of cell viability. Transplantation 1964; 2: 685-94. [CrossRef]

15. Edidin M. A rapid, quantitative fluorescence assay for cell damage by cytotoxic antibodies. J Immunol 1970; 104: 1303-6.

16. Fried J, Perez AG, Clarkson BD. Flow cytofluorometric analysis of cell cycle distributions using propidium iodide. Properties of the method and mathematical analysis of the data. J Cell Biol 1976; 71: 172-81. [CrossRef]

17. Avelar-Freitas B, Almeida VG, Pinto MCX, Mourão FAG, Massensini AR, Martins-Filho OA, et al. Trypan blue exclusion assay by flow cytometry. Braz J Med Biol Res 2014; 47: 307-15. [CrossRef]
18. Cuervo P, De Jesus JB, Saboia-Vahia L, Mendonça-Lima L, Domont GB, Cupolillo E. Proteomic characterization of the released/secreted proteins of Leishmania (Viannia) braziliensis promastigotes. J Proteomics 2009; 73: 79-92. [CrossRef]

19. Kumar A, Samant M, Misra P, Khare P, Sundar S, Garg R, et al. Immunostimulatory potential and proteome profiling of Leishmania donovani soluble exogenous antigens. Parasite Immunol 2015; 37: 368-75. [CrossRef]

20. Braga MS, Neves LX, Campos JM, Roatt BM, Soares RDdOA, Braga $S L$, et al. Shotgun proteomics to unravel the complexity of the Leishmania infantum exoproteome and the relative abundance of its constituents. Mol Biochem Parasitol 2014; 195: 43-53.[CrossRef]

21. Rashidi S, Kalantar K, Hatam G. Achievement amastigotes of Leishmania infantum and investigation of pathological changes in the tissues of infected golden hamsters. J Parasit Dis 2018; 42: 187-95. [CrossRef]

22. Kaneshiro ES, Wyder MA, Wu Y-P, Cushion MT. Reliability of calcein acetoxy methyl ester and ethidium homodimer or propidium iodide for viability assessment of microbes. J Microbiol Methods 1993; 17: 1-16. [CrossRef]

23. Louis KS, Siegel AC. Cell viability analysis using trypan blue: manual and automated methods. Methods Mol Biol 2011: 740: 7-12. [CrossRef]

24. McNicoll F, Drummelsmith J, Müller M, Madore É, Boilard N, Ouellette $\mathrm{M}$, et al. A combined proteomic and transcriptomic approach to the study of stage differentiation in Leishmania infantum. Proteomics 2006; 6: 3567-81. [CrossRef]

25. El Fakhry Y, Ouellette M, Papadopoulou B. A proteomic approach to identify developmentally regulated proteins in Leishmania infantum. Proteomics 2002; 2: 1007-17. [CrossRef]

26. Kumari S, Kumar A, Samant M, Singh N, Dube A. Discovery of novel vaccine candidates and drug targets against visceral leishmaniasis using proteomics and transcriptomics. Curr Drug Targets 2008; 9: 938-47. [CrossRef]

27. Kumari S, Kumar A, Samant M, Sundar S, Singh N, Dube A. Proteomic approaches for discovery of new targets for vaccine and therapeutics against visceral leishmaniasis. Proteomics Clin Appl 2008; 2: 372-86. [CrossRef]

28. Cuervo P, Saboia-Vahia L, Silva-Filho FC, Fernandes O, Cupolillo E, De Jesus J. A zymographic study of metalloprotease activities in extracts and extracellular secretions of Leishmania (Viannia) braziliensis strains. Parasitology 2006; 132: 177-85. [CrossRef]

29. Silverman JM, Chan SK, Robinson DP, Dwyer DM, Nandan D, Foster LJ, et al. Proteomic analysis of the secretome of Leishmania donovani. Genome Biol 2008; 9: R35. [CrossRef]

30. Kim JS, Nam MH, An SSA, Lim CS, Hur DS, Chung C, et al. Comparison of the automated fluorescence microscopic viability test with the conventional and flow cytometry methods. J Clin Lab Anal 2011; 25: 90-4. [CrossRef] 